\title{
The Effect Of Islamic Leadership On Distributive Justice And Management Budget (Apb) And Employee Welfare In Islamic Universities In South Sulawesi
}

\author{
Abdul Rahman Rahim \\ Lecturer of Economic Faculty of Muhammadiyah University Makassar
}

\begin{abstract}
This study aims to identify and to explain the effect of Islamic Leadership application towards distributive justice and employee welfare of Islamic Universities in South Sulawesi Province. The study population of this study are all employees of Islamic Universities in South Sulawesi, with sample of 223 employees from 16 Islamic Universities. The hypotheses was tested using Partial Least Square (PLS) statistical method. Further steps the syar'i qualitiative analysis and kasyflintuitive were conducted by using deductive reasoning based on the quidelines of Allah SWT contained in Al Qur'an and Sunnah of the Prophet.

The study results indicate that the application of Islamic Leadership directly affecting the management of University Budget (APB), Islamic Leadership directly affecting the distributive justice and University Budget has direct effect on employee welfare in Islamic Universities in South Sulawesi Province. In addition, an important finding in this study reveals that apparently the application of Islamic Leadership has indirect effect on employee welfare as well as distributive justice has indirect effect on employee welfare. There is positive significant effecet between Islamic Leadership towards the management of University Budget and Islamic Leadership on distributive justice as well as negatively significant effect between Islami Leadership towards employee welfare and Islamic Leadership towards distributive justice towards distributive justice towards employee welfare.
\end{abstract}

Keywords: Islamic Leadership, Distributive Justice, University Budget Management, employee welfare, Islamic University

\section{Introduction}

Leadership of a nation is critically important to rule and manage people in social and national life by leading people towards prosperity and fend them away from harm. In Islam, leadership is the ability to manifest all the orders of Allah SWT spoken through His prophets. In the Qur'an Sura al-Baqarah (2) : 30 mentioned:

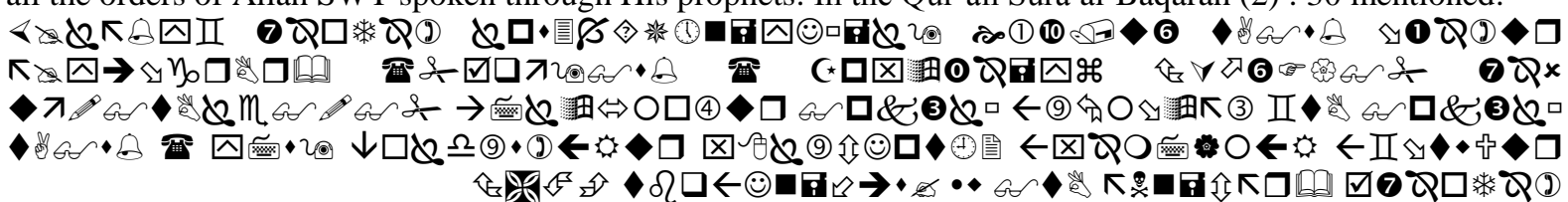

30. Behold, thy Lord said to the angels: "I will create a vicegerent on earth." They said: "Wilt Thou place therein one who will make mischief therein and shed blood?- whilst we do celebrate Thy praises and glorify Thy holy (name)?" He said: "I know what ye know not."

This verse is an argument about the necessity of the Muslims choose and appoint a supreme leader as a unifying figure among all Muslims who can lead the people to implement the laws of Allah on this world. The Muslim scholars have mentioned the characteristics that must be possesed by prominent leaders, among others, are: fair and knowledgeable which allows him to act as judge and mujtahid, does not have physical disabilities as well as sufficiently experienced and no favoritism in carrying out the laws of Allah swt.

Recognizing the importance of the leader figure in Islamic University in its function as caretaker of da'wah in society, therefore the Head of the Islamic universities should equip themselves since early with vast knowledge, nobility of character, as well as Islamic attitudes and behavior both in institutions and in the neighborhood by following the Islamic leadership in the glorious period of Islam (Muhammad Nabiullah to Khulafaurrasyidin).

The success of Islamic University can be measured from it's ability to provide educational services in good and satisfying manners to all of stakeholders, which include the aspects of academic (teaching and education, research and social devotion) and non-academic (facilities and infrastructures, public administration and finance).

The success of Islamic Universities mentioned above should be supported by good governance. As spoken by AllaSWT, in Al-Qur'an Sura Ash-Shaff (61), 4 : 
The Effect Of Islamic Leadership On Distributive Justice And Management Budget (Apb) And...

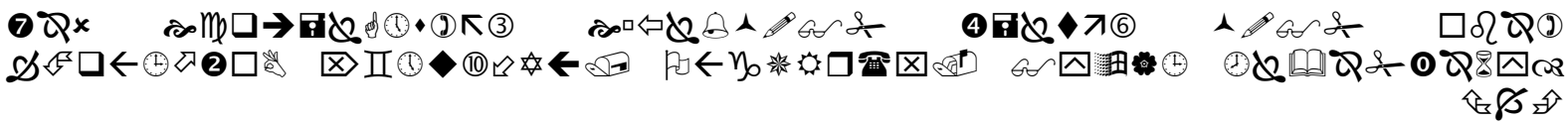

4. Indeed, Allah loves those who fight in His cause in a row as though they are a [single] structure joined firmly

In addition to the good governance, the success of Islamic University also supported with professional attitude. Professional attitude is shown within the incentives paid according to employee's performance and Islamic teaches it's followers to fulfil employee's right of incentives before his sweat dries. In the implementation, Islamic Universities have not completely apply the Islamic teaching, particularly in remuneration aspect. This situation occured due to the management of University Budget in Islamic Universities have not obey the principles of : proportional, professional, not redundant, miserly and greedy.

In the context of distributive justice, the Al-Qur'an and As-Sunnah put firm emphasis on justice, making it one the primary objectives of Shari'a Law.

Allah commands people to act fair to everyone, as in His words :

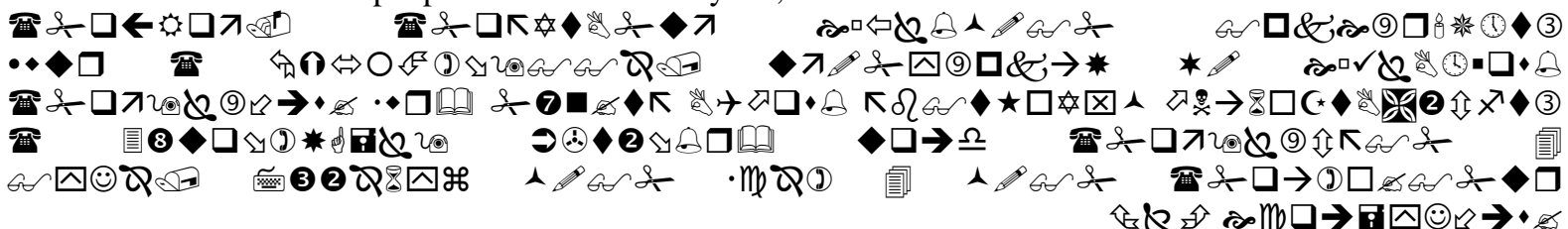

8. O you who believe! Stand out firmly for Allah and be just witnesses and let not the enmity and hatred of others make you avoid justice. Be just: that is nearer to piety, and fear Allah. Verily, Allah is Well-Acquainted with what you do (QS. Al-Maidah (5) : 8)

Fair behaviour as a concern of Al-Qur'an and hadist described above, whenever it's implemented in Islamic Universties it will necessarily improve employees welfare.

The welfare based on Islamic concepts of human (falah) dan happiness (Falah) and a good life firmly emphasize the aspects of brotherhood, socio-economic justice, and the fulfillment of spiritual needs of mankind. This is because human beings have the same status as the Caliph of Allah on earth as well as assuming the role as His servants who will not be able to feel the happiness and peace of mind unless they have achieved true happiness through the fulfillment of material and spiritual needs.

The Phenomenon in Islamic Universities, indicates that leadership have not applying Islamic law by kaffah in the management of University Budget, both in the aspect of revenue sources as well as revenue distribution. In terms of revenue, leadership of Islamic universities still rely on the source of student tuition, still lack of innovation done to obtain source of funds other than the student tuition, such as managing university business units, obtaining national and international grants. In terms of revenue distribution, the allocation mainly channeled to infrastructure development and little is allocated to improving the employee welfare. This is reflected in the remuneration systems that are still below tha standard of average income for employees of Islamic Universities in South Sulawesi Province. Performance -based remuneration model, has not became the general description in Islamic Universities in South Sulawesi. With the low implementation of Islamic law according to kaffah as well as low standard of employee incentives, so that employees have not perceived fairness, which in turn could cause low happiness/well-being in terms of material of employees. Likewise, the placement of employees has not been based on staffing according to employees' expertise, but still relies on interpersonal relation with the leader. Whereas in Islam as it was conveyed by Sayyidina Ali peace be upon him that "to give a job to someone who is not the expert shall lead to destruction". Furthermore, according to researcher observation among the Islamic Universities existed in South Sulawesi, there is only about 40 percent are implementing the programs to improve employees welfare through social secutiry, pension fund, health.

\section{Research Methodology}

This study uses Qur'ani paradigm with quantitative and Kashef approach. In this study population includes all employees (lecturers/professors and non-educative staff/administrasi) of Islamic Universities in South Sulawesi. The samples of study are 370 people who were drawn and based on a sample formula by Slovin.

The variables in this study consists of exogenous variables, intervening variables and endogenous variables. Exogenous variables is Islamic Leadership (X1), while the intervening variables are: University Budget (APB) Islamic Universities (Y1), Distributive Justice (Y2), and Employee welfare (Y3) as endogenous variable.

The study consists of two quantitative analysis tools. The first uses Partial Least Square analysis (PLS) and the second is profit sharing study (al-mudharabah)

Data analysis conducted by using the Kashef analysis method based on Al Qur'an and dan Sunnah 
The Effect Of Islamic Leadership On Distributive Justice And Management Budget (Apb) And...

Rasul which enable to see the real condition un the field.

\section{Study Result And Discussion}

\section{Analysis Model}

To test the study hypothesis, it is used the Partial Least Square method (PLS). PLS is a structural equation model (SEM) based components or variance. The first step in PLS analysis is to test the linearity assumption. The method to test the correlation linearity between construct in this research is conducted by using the estimated curvefit on linear option. The results of linearity test are presented in Attachment 5, and summarized on the following table.

Table 1.

RESULT OF LINEARITY TEST

\begin{tabular}{|c|c|c|c|c|c|c|}
\hline Dependent Variable & & Independent Variable & $\mathrm{R}^{2}$ & $\mathrm{~F}$ & Sig & Conclusion \\
\hline Leadership & $--->$ & University Budget & 0,523 & 340,883 & 0,000 & Linear \\
\hline Leadership & $--->$ & Distributive Justice & 0,106 & 36,739 & 0,000 & Linear \\
\hline Leadership & $--->$ & Welfare & 0,129 & 46,151 & 0,000 & Linear \\
\hline University Budget & $--->$ & Distributive Justice & 0,257 & 108,120 & 0,000 & Linear \\
\hline University Budget & $--->$ & Welfare & 0,137 & 49,610 & 0,000 & Linear \\
\hline Distributive Justice & $--->$ & Welfare & 0,498 & 309,280 & 0,000 & Linear \\
\hline
\end{tabular}

Source: Processed Data, 2012 (Attachment 5)

Based on the results of linear curvefit test it is known that the estimated linear function linier confirmed to be significant. Each linear function is estimated to have a significance of $0,000(<5 \%)$. Furthermore, visually the linear correlation between variables also shown by the scatter plot (Attachment 5) which tend to move to the upper right (positive correlation). These results indicate that the correlation between latent variables tested are linear.

The nest step is Outer Model testing (Measurement Model). Outer model or measurement model is an assessment of realiability and validity of research variables. There are thress criterias used for assessing the outer model: convergent validity, discriminant validity dan composite reliability. Below are the results of convergent validity test.

Table 2.

RESULT OF CONVERGENT VALIDITY TEST

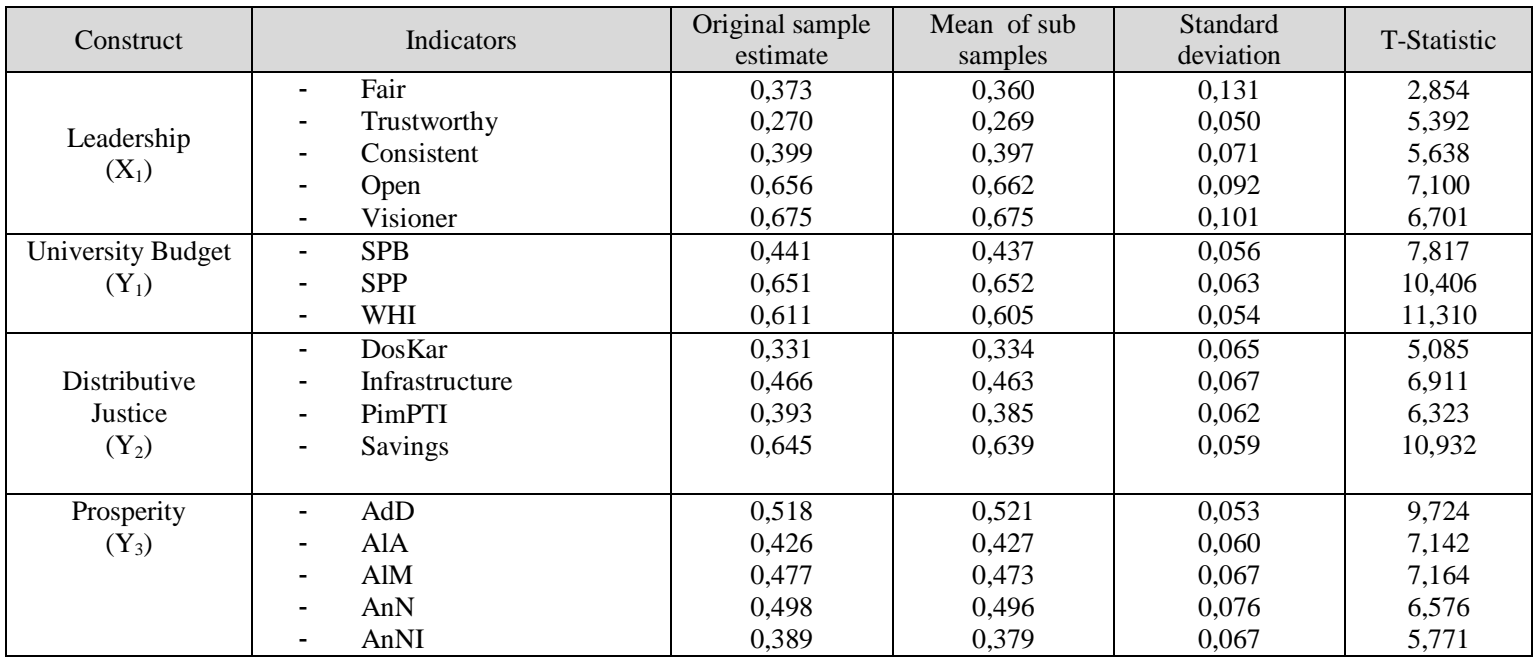

Source: Output SmartPLS

The good measurement is to be unidimensinal, which can accurately maeasure what is measurable (convergent) and does not measure other construct (discriminant). Discriminant validity is used to test whether the indicators of a construct are not highly correlated with indicators of other construct or at least those indicators are correlated lower with the othe construct indicators (Garson, 2002). 
The Effect Of Islamic Leadership On Distributive Justice And Management Budget (Apb) And...

Table 3.

CROSS LOADINGS FOR DISCRIMINANT VALIDITY TEST

\begin{tabular}{|c|c|c|c|}
\hline \multirow{2}{*}{ Construct } & Indicator & Leadership & Welfare \\
\hline \multirow{4}{*}{$\begin{array}{c}\text { Leadership } \\
(\mathrm{X})\end{array}$} & Fair & 0,373 & 0,288 \\
\cline { 2 - 4 } & Trustworthy & 0,270 & 0,256 \\
\cline { 2 - 4 } & Consistent & 0,399 & 0,336 \\
\cline { 2 - 4 } & Open & 0,656 & 0,530 \\
\hline \multirow{2}{*}{ Welfare (Y3) } & Visioner & 0,675 & 0,542 \\
\cline { 2 - 4 } & Ad-Din & 0,490 & 0,518 \\
\cline { 2 - 4 } & Al-Aql & 0,330 & 0,426 \\
\cline { 2 - 4 } & Al-Maal & 0,373 & 0,477 \\
\cline { 2 - 4 } & An-Nash & 0,495 & 0,498 \\
\hline
\end{tabular}

Source: Output Smart PLS

In addition, discriminant validity test other than loading comparison with cross loading need to be strenghtened by examining the AVE dan $\sqrt{A V E}$ comparison with correlation between latent variables. AVE indicates the ability of latent variable value in representing the scores of original data (before extraction). Value Average Variance Extracted (AVE) and correlations between latent variables are presented in the following table.

Table 4.

AVERAGE VARIANCE EXTRACTED (AVE) AND CORRELATION BETWEEN LATENT VARIABLE

\begin{tabular}{|l|c|c|c|c|c|c|}
\hline \multirow{2}{*}{ Construct } & \multirow{2}{*}{ AVE } & \multirow{2}{*}{\begin{tabular}{l} 
CVE \\
\cline { 3 - 6 }
\end{tabular}} & & & \multicolumn{4}{c|}{ Correlation Matrix } \\
\cline { 4 - 7 } & & Leadership & $\begin{array}{c}\text { University } \\
\text { Busget }\end{array}$ & $\begin{array}{c}\text { Distributive } \\
\text { Justice }\end{array}$ & Welfare \\
\hline Leadership & 0,252 & 0,501 & 1,000 & 0,623 & 0,225 & 0,186 \\
\hline University Budget & & & 0.623 & 1,000 & 0,601 & 0,292 \\
\hline Distributive Budget & & & 0.225 & 0.601 & 1,000 & 0,250 \\
\hline Welfare & 0,215 & 0,463 & 0.186 & 0.292 & 0,250 & 1,000 \\
\hline
\end{tabular}

Source: Output SmartPLS

From the table above it is known that the variable of Islamic Leadership is correlated most strongly with Dsitributive Justice. University Budget also correlated most strongly with welfare, while the distributive justice is correlated most strongly with welfare. The value of the correlation between these variables, all lower than the $\sqrt{A V E}$ value of the four latent variables, so it is concluded that measurement of the four latent variables have good discriminant validity, which can be distinguished from other latent variable measurement.

\section{Reliability Test}

Reliability reflects the consistency of measurement results conducted repeatedly on the same subject. If the results are consistent, then the measuring instrument is considered to be reliable or trustworthy. Reliability testing using the composite reliability, the results of which are presented in the following table.

Table 5.

COMPOSITE RELIABILITY

\begin{tabular}{|c|c|}
\hline Konstruct & Composite Reliability \\
\hline Leadership & 0,601 \\
\hline University Budget & $\mathrm{NaN}$ \\
\hline Distributive Justice & $\mathrm{NaN}$ \\
\hline Welfare & 0,576 \\
\hline
\end{tabular}

Source: Output SmartPLS

Based on Table 5 the variable measurement reliability level is good, because each latent variable has value of $>0,70$. Composite reliability values of 4 latent variables ranged from 0,795 up to 0,854 . This means that the indicators are supporting each other to measure the respective latent variables 


\section{Inner Model Test (Structrural Model)}

The next step in PLS analysis is to test the inner model or structural model. The results were processed with SmartPLS as presented in Figure 1.

\section{Figure 1.}

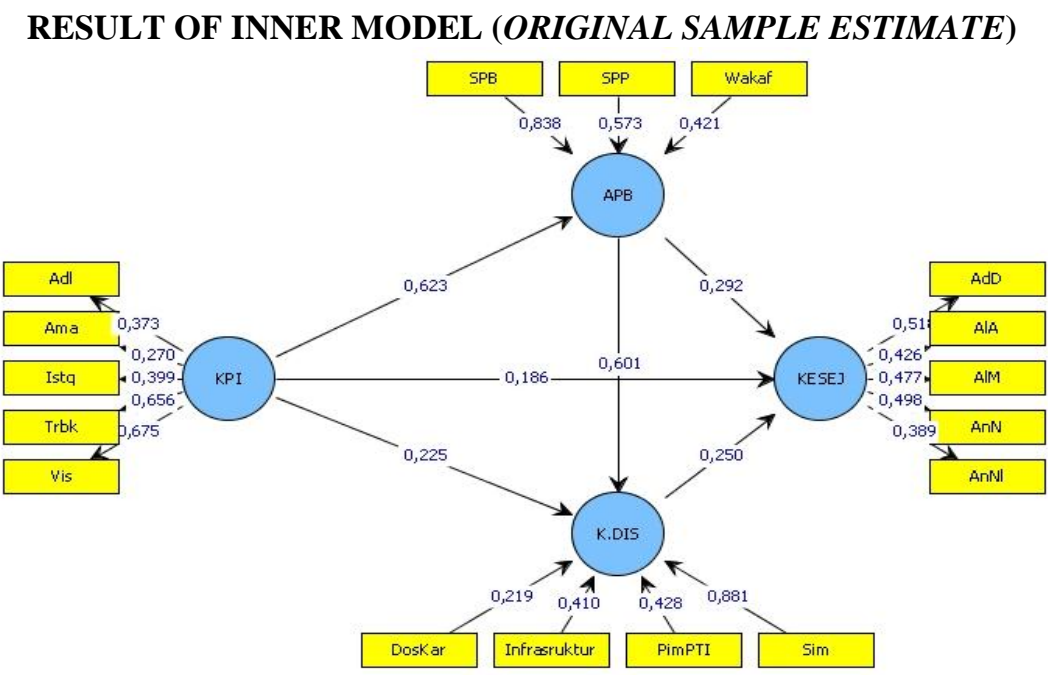

Source: Output SmartPLS

Table 6.

RESULT OF R-SQUARE

\begin{tabular}{|c|c|c|c|}
\hline Equation & Exogenous Variable & Endogenous Variable & R-square \\
\hline 1 & Leadership & University Budget & 0,388 \\
\hline 2 & Leadership, University Budget & Distributive Justice & 0,581 \\
\hline 3 & $\begin{array}{c}\text { Leadership, university Budget, Distributive } \\
\text { Justice }\end{array}$ & Welfare & 0,414 \\
\hline
\end{tabular}

Source: Output SmartPLS

Furthermore, based on the value of determinant coefficient of each endogenous variable Q2 sought by using the formula :

$\mathrm{Q}^{2}=1-\left(1-\mathrm{R}_{1}^{2}\right)\left(1-\mathrm{R}_{2}{ }^{2}\right)\left(1-\mathrm{R}_{3}{ }^{2}\right)$

Remarks:

$\mathrm{R}_{1}^{2}=$ determinant coefficient for endonegous variable of University Budget,

$\mathrm{R}_{2}{ }^{2}=$ determinant coefficient for endonegous variable of Distributive Justice

$\mathrm{R}_{3}{ }^{2}=$ determinant coefficient for endonegous variable of Welfare.

Thus:

$\mathrm{Q}^{2}=\{1-(1-0,388)(1-0,581)(1-0,414)\}$

$Q^{2}=\{1-0,150\}=0,850$

Based on the determinant coefficient of the three dependent variables in the model, it is known that Stone-Geisser Q Square is 0,850 . These results indicate that the model has good feasibility, being able to explain the information contained in the original data for $85 \%$, while the remain is explained by other variables and error variable. The total value of the determinant coefficient is high, so that the model is feasible to be interpreted.

\section{Hypotheses Testing}

There are six hypotheseses with direct effect and 5 hypotheseses with the mediation proposed in this study. The hypotheses testing on PLS Analysis, is basically testing the significance of path coefficient existed on the model. To conclude whether the paths or research hypotheseses proven, it is used the Cut-off value of $t_{\text {valued }}=1,96$ (Ghozali, 2011). Thus, if $t_{\text {valued }}$ on the tested path $\geq 1,96$, then the research hypotheseses are proven. The results of parh coefficients are presented in Table 7. 
Table 7.

RESULT OF HYPOTHESES TEST

\begin{tabular}{|c|c|c|c|c|c|c|}
\hline Hipt. & Path & $\begin{array}{c}\text { Original } \\
\text { sample } \\
\text { Estimate }\end{array}$ & $\begin{array}{c}\text { mean of } \\
\text { sub samples } \\
\text { deviation }\end{array}$ & $\begin{array}{c}\text { Standard } \\
\text { deStatistic*) }\end{array}$ & Conclusion \\
\hline $\mathrm{H}_{1}$ & $\begin{array}{c}\text { Islamic Leadershio -> University } \\
\text { Budget }\end{array}$ & 0,623 & 0,632 & 0,081 & 7,724 & $\mathrm{H}_{0}$ rejected \\
\hline $\mathrm{H}_{2}$ & $\begin{array}{c}\text { Islamic Leadership-> Distributive } \\
\text { Justice }\end{array}$ & 0,225 & 0,239 & 0,078 & 2,893 & $\mathrm{H}_{0}$ rejected \\
\hline $\mathrm{H}_{3}$ & Islamic Leadership -> Welfare & 0,186 & 0,185 & 0,117 & 1,591 & $\begin{array}{c}\mathrm{H}_{0} \\
\text { Accepted }\end{array}$ \\
\hline $\mathrm{H}_{4}$ & University Budget -> Welfare & 0,292 & 0,284 & 0,140 & 2,084 & $\begin{array}{c}\mathrm{H}_{0} \\
\text { Rejected }\end{array}$ \\
\hline $\mathrm{H}_{5}$ & Distributive Justice-> Welfare & 0,250 & 0,268 & 0,136 & 1,839 & Accepted \\
\hline $\mathrm{H}_{6}$ & University Budget -> Distributive & 0,601 & 0,603 & 0,071 & 8,412 & $\mathrm{H}_{0}$ rejected \\
\hline
\end{tabular}

Source: Processed Data, 2012

Remarks:

*) : signifficant $5 \% \quad$;wo side test $\mathrm{t}_{\text {tabel }}=1,96$

\section{Mediation Test}

Mediation test is conducted based on the procedure by Baron and Kenny (1986). The results of mediation test according to those criterias for each equation in the model and theoretical studies are summarized in the following table.

Table 8. Summary of Mediation Test Result

\begin{tabular}{|cl|l|}
\hline \multicolumn{1}{|c|}{ Tested Mediation } & \multicolumn{1}{c|}{ Result } \\
\hline 1. & $\begin{array}{l}\text { Effect of Islamic Leadership on distributive justice mediated by } \\
\text { University Budget management. }\end{array}$ & partially mediated \\
\hline 2. & $\begin{array}{l}\text { Effect of Islamic Leadership on employee welfare mediated by } \\
\text { University Budget management }\end{array}$ & partially mediated \\
\hline 3. & $\begin{array}{l}\text { Effect of Islamic Leadership on employee welfare mediated by } \\
\text { distributive justice. }\end{array}$ & partially mediated \\
\hline 4. & $\begin{array}{l}\text { Effect of University Budget management on employee welfare } \\
\text { mediated by distributive justice }\end{array}$ & partially mediated \\
\hline 5. & $\begin{array}{l}\text { Effect of Islamic leadership on employee welfare mediated by } \\
\text { University Budget management and distributive justice. }\end{array}$ & fully mediated \\
\hline
\end{tabular}

Source : processed data

\section{Discussion}

1. The hypotheses test results showed that Islamic leadership affecting the University Budget management, with a contribution of 7,724 (significance 5\%). This illustrates that the more Islamic the leadership of universities, the better management of University Budget concerned. Islamic university leaders as main caretaker of the institution is indeed plays significant role in determining the management of University Budget. It has become the task of Islamic universities leaders in planning the University Budget that will be approved, implemented, and accounted to the Organizing Board (foundation), civitas academica as well as to community as the stakeholder. Additionally, in an effort to achieve the goals, leaders of Islamic universities Islam also conduct the public policy directives, establish rules, norms and benchmark of university educational organization based on the approval of university senate that has been stated in University Budget Structure as the guidance of operational implementation for one year budget period. In the view of Islam, the Islamic principle regarding fiscal policy, the revenue and expenditure budget aims to develop a society based on balanced distribution of wealth by putting the material and spiritual values at the same level. Fiscal policy is considered as a tool to regulate and control people behavior which can be influenced through incentives or disincentives provided to increase government. Therefore, Islamic fiscal policy as a policy that manage the government expenditure and revenue which aims to maintain economic stability and promote growth.

From this it can be concluded that the leadership of the Islamic universities is crucial to University Bduget management. University budget management quality is significantly determined by the quality of the leaders, including the conformity of University budget management with the foundation, philosophy and principles of Islam. However, the leadership of Islamic University in South Sulawesi Province in allocating 
budget is primarily to the infrastructure and very small allocation to employee incentives which can be classified as ruthlessness.

2. Based on the analysis results it can be concluded that the leadership in Islamic Universities significantly contribute to distributive justice with significance level of t 2,893 ( $\alpha=5 \%)$. Therefrom, this means that there is significant effect between Islamic leadership towards distributive justice which indicates that the better Islamic leadership applied in Islamic Universities of South Sulawesi Province will lead to the highest level of distributive justice. Since the value of t test is significant so that the effect of Islamic leadership towards distributive justice is confirmed.

The Islamic leadership of Islamic Universities in South Sulawesi from the perspective of fairness can be viewed from the policy applied regarding income distribution to : a) educative and non-educative employees which constitute of : salary, incentive, health allowances, and pension fund which are paid at the and of the month, when every academic activity has been implemented, while the pension fund is paid at post service period. In addition, Islamic Universities also allocate a certain amount of fund for savings which aimed to be the reserve fund. It indicates that not all of the universities' annual income spent on operational and infrastructure expenditures but partially deposited for saving/reserve funds.

The Al-Qur'an and Al-hadist based approach consists of four main principles of leadership namely: responsibility within the organization, principle of Tauhid ethics, principle of just, and principle of modesty. Islam commands justice in every aspect of human life, as it will lead to the increased of employee welfare.

3. From the analysis results indicate that Islamic leadership does not affect the employee welfare with a contribution of 1,591. This shows that the role of Islamic Leadership has not been considered important in improving the welfare of employees in Islamic Universities.

Empirical facts that occured indicates that the leaders of Islamic Universities in fulfilling employees welfare which consists of: ad-Din (religious), an-Nafs (soul), al-Aql (intellectual/knowledge), al-Maal (wealth) and an-Nasl (descendants) have been relatively well executed, it can be seen from the policies and programs of Islamic Universities among others : ad-Din, to provide more opportunities to implement Islamic activities, such as: Emotional Spiritual Quetion (ESQ), Darul Arqam, Baitul Arqam, preaching training/up grading, routine Islamic review, where all the implementations are well institutionalized, structured, planed even for Muhammadiyah University of Makassar and for Indonesias Muslim. In addition to the programs mentioned above, there is also program of annual Umrah (pilgrimage) and Hajj for employees (educative and non-educative employees) with excellent performance. An-Nafs, leaders of Islamic Universities give the feeling of secure (peace of mind) to all employees both in forms of material and immaterial. The examples of material securedness: pension fund, health insurance, while the immaterial securedness such as: embedded understanding of each employees (educative and noneducative) that to carry out the task in Islamic Universities is a form of worship and therefore if implemented sincerely it shall gain reward from Allah swt. Allah swt. will gives unexpected sustenances. Al-Aql, leaderships in Islamic Universities promoting quality improvement of education in the forms of : improvement of employees quality (educative and non-educative) through further studies of degree and non-degree basis (sustainable) namely: bachelor, master and doctoral degree education, while for nondegrees study such as training and education, skill courses and workshop in Islamic Universities namely: State Islami University of Alauddin, Muhammadiyah University Makassar, Indonesian Muslim University of Makassar (UMI), Muhammadiyah University Pare-Pare, STIE Muhammadiyah Palopo, which have implemented the employees improvement programs and hundreds of employees have experienced the facilities funded by Islamic Universities from University budget, National Budget (Directorate General of High Education), regional government as well as self-funding. Al-Maal, Islamic leaderships in Islamic Universities in fulfilling employees (educative and non-educative), one of important element is the availability of housing facilities for employees through the provosion of mortgage facilities (residential for employees of Islamic Universities), soft loans provided by the Islamic Universities for employee to own a house. In addition, leaders of Islamic Universities also provide loan for employees to buy auto vehicles through bank credit facility or loan facility sourced from the budget of Islamic Universities. The facilities mentioned above are provided by Islamic Facilities such as Muhammadiyah University (Unismuh) Makassar, Makassar State University (UNM), Indonesian Muslim University (UMI), however several other Islamic Universities have not provided such facilities due to budget constraints.. Al-Maal also can be obtained by Employees (educative and non-educative) through monthly salary, incentive and honorarium payment. An-Nasl, leaders of Islamic Universities in the efforts to increase employee welfare (educative and non-educative) provide donation or loan to for employees' children educational fund. In addition, Islamic universities also provide health care donation for the family of employees. Such cases have been implemented by Islamic Universities namely : State Islamic University of Alauddin (UIN), UMI, Muhammadiyah University Makassar through the facilities provided such as hospitals, polyclinics, health 
house owned by concerned Universities. While other Islamic Universities have not provided health fasilities however they facilitate the employees to acquire health care at hospitals or polyclinics existed at respective area.

To see the results of hypotheses tersting which show that there is no direct effect of Islamic leadership toward employee welfare in Islamic Universities in South Sulawesi, yet Islamic leadership has indirect effect on employee welfare through the good management of University Budget and the establishment of distributive justice in Islamic Universities. These results indicates that the effectiveness of Islamic leadership role and the management of University budget depend on the leaders capability of Islamic Universities and the university budget is distributed fairly for the purpose of employees welfare.

4. The analysis results show that the variable of University Budget of Islamic Universities has significant effect on employee welfare with the value of significance of t 2,084 $(\alpha=5 \%)$. This indicates that there is significant relation between University Budhet and employee welfare of Islamic Universities which show that better management of University budget will contribute to better prosperity perceived by employees. Because the $t$ test is significant so that the effect of University Budget Management on employee welfare is confirmed.

Despite the management of University Budget of Islamic Universities in South Sulawesi Province show variability on the amount of revenue however there is a desire of the leaders to improve employee welfare because one of the purpose of Islamic teachings is the achievement of human prosperity.

From this it can be concluded that leaders of Islamic universities crucially determine the University Budget management. University budget management quality is determined by the quality of leaders, including conformity with Islamic basic principles in University budget.

5. From the analysis results known that variable of distributive justice is not a significant influence on employee welfare with the value of significance $t 1,839(\alpha=5 \%)$. This means that there is no significant effect between distributive justice on employee welfare in Islamic Universities which indicates that the bigger budget allocated of infrastructure, leader allowances and university saving as indicators of distributive justice variable, then it is perceived as smaller allocation for employee. Thus because the $t$ test is not significant so that the effect of distributive justice on employee welfare is not proven.

Empirical facts show that in some Islamic Universities mostly university budget allocated for the improvement of infrastructure, leaders allowances, and university savings/reserves, the little remain for employee welfare in forms of salary and other allowances. Generally, the condition of Islamic Universities in South Sulawesi is still on the stage of infrastructure improvement/development, so this situation is used as a justification by the leaders of Islamic Universities to allocate substantial funds for infrastructure and facility development. Particularly for university reserve fund, there is a growing assumption that the success leadership in Islamic University shown by the large amount of savings. This is the assumption that encourage leaders to save expenses, including by pressing the expenses for employee salary for the purpose of saving. With the concept of distributive justive such this, then the employee welfare can be realized, so that distributive justice plays significantly important role to improve employee welfare.

6. From the analysis results it is showed that the variable of University budget management of Islamic Universities provide a significant influence on distributive justice with significance value of t $8,412(\alpha=$ $5 \%$ ). This means that there is significant effect between the management of Islamic University budget management on distributive justice that indicates better university budget management will cause better distributive justice. Because the $t$ test is significant so that the effect of University budget management on distributive justice is confirmed.

The effect of University budget management on distributive justice in Islamic Universities is critically determined by how the university budget is defined, managed and implemented by university leaders. Because within the structur of University budget management, in addition to the description of revenue elements, there are also allocation for distribution of wealth in the forms of expenditure items which are expected to be fair, as is prescribed in Islamic teaching, because if it is not, then certainly would appear disadvantages.

\section{Conclusion}

1. Application of Islamic Leadership significantly influence the University budget management in Islamic Universities in South Sulawesi.

2. Application of Islamic Leadership significantly influence the distributive justice of Islamic Universities in South Sulawesi.

3. Application of Islamic Leadership is indirectly influence the employee welfare in Islamic Universities in South Sulawesi.

4. University Budget Management influence the distributive justice of Islamic Universities in South Sulawesi. 
5. Distributive justice is not significantly influence the employee welfare in Islamic Universities in South Sulawesi.

6. The leaders of Islamic Universities plays important role in determining the University Budget management. The quality of university budget management is crucially determined by the leaders quality, including conformity of University budget with the phylosophy, fundamentals and principles of Islam.

7. The employee welfare of Islamic Universities, is largely determined by how far the leaders of Islamic Universities fulfilling material and spiritual needs of employees. So that the more concern of a leader, then the employee welfare will be higher.

8. In term of management of University Budget of Islamic University in South Sulawesi Province, apparently there still no fair distribution between infrastructure/physical development expenditure with employee salary/incentive as well as structural allowance expenditures, so that in average the employees are still underpaid /muzaqqi.

9. In the situation of University Budget allocation/distribution in Islamic Universities of South Sulawesi Province which relatively not proportional and balance between the cost of infrastrucure construction and salary/incentive apparently those Islamic Universities remain operating, although still not optimal because the relatively high loyalty of employees and leaders.

\section{Bibliography}

[1]. Al Bayan, 2008. Shahih Bukhari Muslim. Bandung : Jabal Munawwir, Ahmad Warson. Al-Munawwir

[2]. Baswir, 2009. http://managementwascool.blogspot.com/2009/05/analisa-sebab-krisis-keuangan-amerika.html

[3]. Carbonell, AF., 2002. Subjective Questions to Measure Welfare and Well-Being. Discussion paper. Tinbergen Institute. Amsterdam.

[4]. Chapra, M. Umar. 2000. Islam dan Tantangan Ekonomi , terj. Ikhwan Abidin, Jakarta : Gema Insani Press

[5]. Djazuli, A. 2003. Fiqh Siyasah: Implementasi Kemaslahatan Umat dalam Rambu-rambu Syariah, Jakarta: Kencana.

[6]. Gasperz, Vincent, 2002. Total Quality Management, Jakarta:Airlangga

[7]. Ghozali, Imam. 2011. Structural Equation Modeling. Metode Alternatif dengan Partial Least Square (PLS). Edisi 3. Undip Press. Semarang

[8]. Hafidhuddin, Didin dan Tanjung, Hendri, 2003. Manajemen Syariah dalam Praktek. Gema Insani. Jakarta.

[9]. Harris, Lynette., 2002. Achieving a Balance in Human Resourcing between Employee Rights and Care for the Individual. Business and Professional Ethic Journal, 21(2), 45-60.

[10]. Haq, Hamka, 2007. Al-Syathibi Aspek Teologis Konsep Mashlahah Dalam Kitab al-Muwafaqat. Jakarta : Erlangga.

[11]. Junaidi, Wawan, 2010. http://wawan-junaidi.blogspot.com/2010/02/model-pemimpin-yang-efektif-model-of.html

[12]. Marshall, Sheila., Adams, Gerald., \& Ryan, Bruce A., 2001. Distributive Justice Reasoning in Families with Adolescent. Journal of Family Issues, 22(1), 107-123.

[13]. Nowack, Kenneth, 2004. Does Leadership Practise Affect a Phsicologically Heallty Workplace, Working Paper, Consulting Tool Inc

[14]. Qardhawi, Yusuf. 2001, Norma dan Etika Ekonomi Islam. Terj. Zainal Arifin dan Dahlia Husin, Jakarta: Gema Insani Press

[15]. Rahardjo, Dawam, 2002. Sejarah Ekonomi Islam, The International Institute of Islamic Thought, Jakarta, Indonesia

[16]. Saragih, Sebastian, dkk. 2007. Kerangka Penghidupan Berkelanjutan. Jakarta

[17]. Sedarmayanti, 2001, Sumber Daya Manusia dan Produktivitas Kerja, Mandar Maju, Bandung

[18]. Setiadji, Bambang, 2002. Wage Differential in Indonesian Manufacturing Industries. Jurnal Ekonomi Malaysia. Vol. 36 p. $81-98$

[19]. Setiadji, Bambang, 2002. Upah Antar Industri di Indonesia . Cetakan Pertama,Muhammadiyah University Press.

[20]. Solimun, Nurjannah, Adji Ahmad Rinaldo, 2006. "Pemodelan Persamaan Struktural : Pendekatan PLS dan SEM". Modul Pelatihan Aplikasi Software Smart PLS dan AMOS. Fakultas MIPA dan Program Pascasarjana. Universitas Brawijaya Malang.

[21]. Suardi, R., 2003. Sistem Manajemen Mutu ISI 9000:2000, Penerapannya untuk Mencapi TQM. PPM. Jakarat

[22]. Sudrajad, akhmad. 2008. Teori-Teori Motivasi http://akhmadsudrajat.wordpress.com/2008/02/06/teori-teori-motivasi/

[23]. Sugiyono. 2001. Statistik Nonparametrik untuk Penelitian. Bandung: Alfabeta.

[24]. Thornhill, Adrian., and Saunders, Mark N. K., 2003. Exploring Employees' Reactions To Strategic Change Over Time: The Utilization of an Organizational Justice Perspective. Journal of Management, 11(1), 66-84.

[25]. Tjahyono, Heru Kurnianto, 2008. Pengaruh Keadilan Keorganisasian Pada Kepuasan Individu, dan Komitmen Keorganisasian Dengan Modal Sosial Sebagai Variabel Moderator. Disertasi Doktor Psikologi Industri, dan Organisasi Universitas Gadjah Mada. Yogyakarta

[26]. Tohyyar, Huzni, 2009. Konsep Kepemilikan Negara Menurut Mutakallimin, Tajdid : Jurnal Ilmu-Ilmu Agama Islam dan Kebudayaan, Ciamis. Jawa Barat.

[27]. Umar, Husein. 2004. Metode Penelitian untuk Skripsi dan Tesis Bisnis. Cetakan ke-6. Jakarta: PT Raja Grafindo Persada.

[28]. Wirawan, 2002. Kapita Selekta : Teori Kepemimpinan Pengantar untuk Praktek dan Penelitian. Yayasan Bangu Indonesia dan Uhamka Press. Jakarta

[29]. Wahjosumidjo. 2007. Kepemimpinan Kepala Sekolah. Jakarta: Raja Grafindo Persada

[30]. Yamit, Zulian. 2004. Manajemen Kualitas Produk dan Jasa. Yogyakarta: Ekonisia.

[31]. Zadjuli, Suroso Imam, 2007. Reformasi Ilmu Pengetahuan Dan Perspektif Ekonomi Islam Di Indonesia. Makalah Program Doktor Ilmu Ekonomi Islam Univ. Airlangga Surabaya.

[32]. 2008. SIZ Model Analisis Pembangunan dan Kemiski nan di Indonesia Doktor Ilmu Ekonomi Islam. Univ. Airlangga Surabaya

[33]. 2009. "Sistim Pendidikan dan Ekonomi Islam Sebagai Solusi Meniadakan Kemiskinan dan Ketidakadilan dalam Rangka Membangun Masyarakat Madhani Secara Kafah”. Makalah pada Semiloka Ekonomi Islam Sebagai Sistem Pendidikan Ilmu Ekonomi di Indonesia di Auditorium Moh. Djazman UMS - Surakarta 